\title{
Effects of pressing technology of oil separation and heat treatment on the protein value of low-glucosinolate rapeseed cake for non-ruminants*
}

\section{Rune Nyström ${ }^{1}$, Barbara Pastuszewska ${ }^{2}$, Lucyna Buraczewska ${ }^{2}$, Unto Tulisalo' and Anna Ochtabińska ${ }^{2}$}

\author{
'Mildola $O y$ \\ Fin-02401 Kirkonummi, Finland \\ ${ }^{2}$ The Kielanowski Institute of Animal Physiology and Nutrition, \\ Polish Academy of Sciences \\ O5-110 Jablonna near Warsaw, Poland
}

(Received 16 Fcbruary 1996; accepted 9 July 1996)

\begin{abstract}
The effects of two pressing methods vs solvent extraction, and of different heat treatment of the press cake on the nutritional value of rapeseed protein were studied. Rapeseed cake contained more fat ( $9-12$ vs $4-5 \%$ DM) and less protein ( $31-33$ vs $36 \%$ DM) than solvent extracted meal while digestibility and biological value of cake and meal protein for rats did not differ significantly $(80.9 \mathrm{vs}$ 79.2 and 86.1 vs 83.5 , respectively). The incubation of seeds prior to pressing aiming at activation of endogenous enzymes had variable effects. The first batch of the pre-incubated cake had lower lysine content ( 4.91 vs $5.76 \mathrm{~g} / 16 \mathrm{~g} \mathrm{~N}$ ), ileal digestibility of lysine in pigs ( $57.8 \mathrm{vs} 72.3 \%$ ) and biological value of protein for rats ( $78.8 \mathrm{vs} 86.8$ ) as compared with solvent meal. The second batch evaluated in rats had lower biological value of protein ( $81.9 \mathrm{vs} 86.1$ ) only as compared with cake from nonincubated seeds. Heat treatment of the cake on pilot scale (autoclaving or toasting and heat - moisture treatment at 120 and $140^{\circ} \mathrm{C}$ ) reduced glucosinolate content from 22.9 to $9.1 \mu \mathrm{m} / \mathrm{g}$ fat-free $\mathrm{DM}$ and tended to decrease protein digestibility (from 80.4 to 76.6 ) but not its biological value.

Each stcp of the industrial technology of pressing (pre-pressing, full pressing, toasting, heating) resulted in lower glucosinolate content (decrease from 13.7 to $5.8 \mu \mathrm{m} / \mathrm{g}$ fat-free DM) and thyroid
\end{abstract}

\footnotetext{
* Some results were presented on 1 th International Rapeseed Congress, Cambridge (UK), 4-7 July 1995
} 
weight of rats (from 20 to $11 \mathrm{mg} / 100 \mathrm{~g} \mathrm{BW}$ ) while growth performance of animals and nutritional value of the cake protein were not affected. It was concluded that properly heated rapeseed press cake may have similar protein value for non-ruminants as solvent extracted meal.

KEY WORDS: rapeseed cake, pressing, heating, protein digestibility, rats, pigs

\section{INTRODUCTION}

The most commonly used technology for oil separation from rapeseed involves prepressing of flaked and cooked seeds followed by solvent extraction and desolventizing - toasting of the meal. This process is both labour and equipment intensive; therefore more cost effective, pollution free and safe operations are searched for (Loutas, 1991).

Some procedures alternative to solvent extraction have been proposed and tested on experimental scale such as expression of oil with single or twin-screw expellers (Isobe et al., 1991), pressing after pre-treatment of seeds with enzymes to enhance oil recovery (Sosulski and Sosulski, 1991), or aqueous enzymatic process (Jensen et al., 1991). The most extensively evaluated parameters were the yield and quality of oil while less attention was paid to the effects of pressing technology on the nutritional value of expeller cake and on the need of post pressing heat treatment.

Moderate heat treatment of rapeseed meal or cake is necessary to inactivate myrosinase and to remove the degradation products of glucosinolates still present in double-low rapesecd. Negative effects of glucosinolates on fecd intake, growth rate and thyroid functions were observed in many animal species (for review see Mawson et al., $1994 \mathrm{a}, \mathrm{b}$ ). It is also well known that overheating may decrease total and available lysine content and impair protein utilization (Anderson-Hafermann et al., 1993; Grala et al., 1994; Jensen et al., 1994). Thus heating parameters such as temperature, duration and moisture should be carefully chosen to ensure the high protein value of processed rapeseed feeds.

The study was set up as a part of an investigation on the choice of the proper technology of pressing rapeseed oil without solvent extraction in a Finnish oil mill.

The objective was to estimate the effects of different pressing methods (as compared with solvent extraction), and heat moisture treatments on the nutritional value of protein of the cake produced on experimental (pilot) scale. The nutritional value of the cake issued from the consecutive steps of industrial pressing in the oil mill was verified.

The main criteria of the nutritional value of rapeseed products was protein, fat and glucosinolate contents, protein utilization (digestibility and biological value) and growth performance estimated with rats. Ileal and total digestibility of 
protein and amino acids was determined in pigs to compare the effects of the two methods of oil scparation.

\section{MATERIAL AND METHODS}

\section{Technological treatments}

\section{Methods of oil separation}

Three methods of oil separation from rapeseed (Finnish 00 type) were compared: standard procedure of solvent extraction which final product was rapeseed oil meal (RSM), and two experimental procedures of pressing which final product were rapeseed cakes (RC). RSM was produced in the oil mill equipped with desolventizer - toaster working both with live and indirect steam. At the end of the process meal was treated with pressurized heat-moisture for a short time. The cakes were produced in a pilot plant using two procedures:

1. rape seeds were incubated $4 \mathrm{~h}$ in $50^{\circ} \mathrm{C}$ at $30 \%$ moisture to activate endogenous enzymes, flaked, heated to $80^{\circ} \mathrm{C}$ and pressed on a Reinartz continous screw press, type Ap VII (the cake was designated as $\mathrm{RC}_{\mathrm{en} \text { ) }}$ ),

2. nonincubated seeds were heated and pressed as in procedure 1 (the cake was designated as $\mathrm{RC}$ ).

Two batches of RSM (RSM 1 and RSM 2), two $\mathrm{RC}_{\mathrm{enz}}\left(\mathrm{RC}_{\mathrm{enz}} 1\right.$ and $\left.\mathrm{RC}_{\mathrm{enz}} 2\right)$ and one $\mathrm{RC}$ were evaluated.

\section{Heat moisture treatment of the cake}

The cake produced according to procedure 2 (nonincubated) was further submitted in a pilot plant to different heat-moisture treatments. The cakes treated as follows were evaluated:

- non treated $\left(\mathrm{RC}_{\mathrm{i}}\right)$, control,

- autoclaved during $15 \mathrm{~min}$ to $120^{\circ} \mathrm{C}$ at $18 \%$ moisture $\left(\mathrm{RC}_{\text {aut }}\right)$,

- toasted during $45 \mathrm{~min}$ in $100^{\circ} \mathrm{C}$ at $18 \%$ moisture and nexlly heat-pressure treated at $120^{\circ} \mathrm{C}\left(\mathrm{RC}_{\mathrm{t120}}\right)$,

- as above, but heat-pressure treated at $140^{\circ} \mathrm{C}\left(\mathrm{RC}_{\mathrm{t} 140}\right)$.

\section{Industrial processing in the oil mill}

The flow chart of the industrial process based on pressing the oil without solvent extraction is shown in Figure 1. The samples of cake were taken after pre-pressing $\left(\mathrm{RC}_{\mathrm{pp}}\right)$, full pressing $\left(\mathrm{RC}_{\mathrm{p}}\right)$, full pressing and toasting during $45 \mathrm{~min}$ 


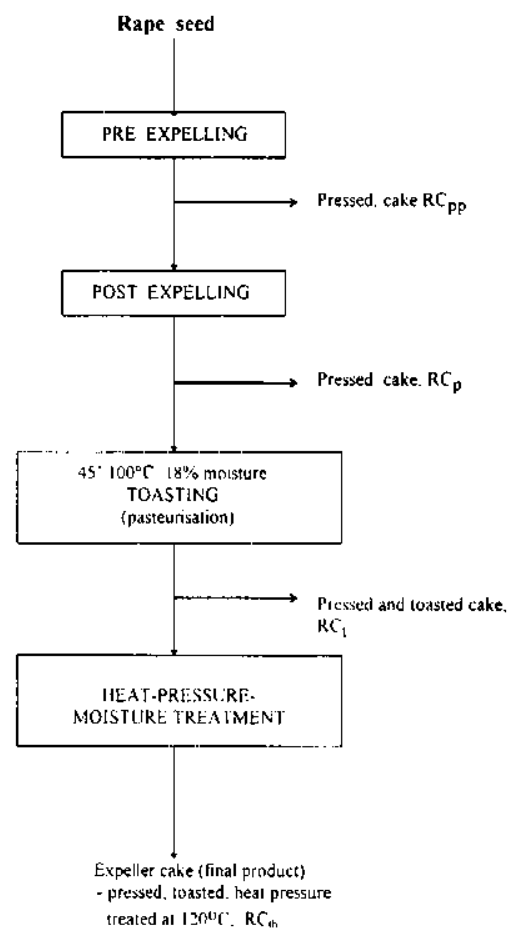

Figure 1. Flow chart of the industrial procedure of pressing rapeseed in the oil mill

at $100^{\circ} \mathrm{C}, 18 \%$ moisture $\left(\mathrm{RC}_{\mathrm{t}}\right)$, full pressing toasting and heat-moisture pressure treatment at about $120^{\circ} \mathrm{C}\left(\mathrm{RC}_{\mathrm{th}}\right.$, the final industrial product $)$.

\section{Evaluation of rapeseed products}

\section{Experiment with pigs}

Six Large White $\mathrm{x}$ Landrace castrated male pigs of about $35 \mathrm{~kg}$ body weight were cannulated by insertion of $\mathrm{T}$-shaped cannula in the ileum and were fed the experimental diets according to change over $(2 \times 3)$ design. The semisynthetic diets containing about $14 \%$ protein of the cvaluated products, were fed each to 6 pigs at the level of 2.9 times their maintenance requirement for energy. After seven days of adaptation, faeces ( 3 days) and nextly digesta $(3 \times 12 \mathrm{~h})$ were collected and immediately frozen. After collection period the samples were pooled for each animal and freeze dried for analysis. 
Digestibility of protein and amino acids in the small intestine (ileal digestibility) and in total gastrointestinal tract (total digestibility) of the standard rapeseed oil meal (RSM1) and preincubated cake $\left(\mathrm{RC}_{\mathrm{enz}} 1\right)$ was determined.

\section{Tests with rats}

Balance and growth experiments were performed on rats. True digestibility (TD) and biological value (BV) of protein was determined by Thomas-Mitchell $\mathrm{N}$-balance method on $30 \pm 1$ day old male rats from Ifz:JAZ outbred herd, 8 animals per treatment. Net Protein Utilization (NPU) was calculated according to formula NPU $=\mathrm{TD} \times \mathrm{BV} / 100$. Feed intake and growth rate were measured in growth tests of 3 weeks duration, performed on male rats $25 \pm 1$ day old, 8 animals per treatment. At the end of the experiment the rats were killed, liver and thyroid were excised and weighed.

The semisynthetic diets contained rapeseed products as the only source of protein at the level corresponding to 9.5 per cent of $\mathrm{N} \times 6.25$, and were equalized in contents of fat by addition of rapeseed oil, and of fibre by addition of cellulose. Minerals were added according to NRC and vitamins according to AOAC (1975). Sucrose was included at $12.0 \%$ and wheat starch to make up $100 \%$.

The rats were maintained individually in cages allowing for the control of feed intake and collection of faeces and urine. Feed intake in N-balance experiments was limited to about $10 \mathrm{~g} \mathrm{DM}$ rat/day while in growth tests feed was offered $\mathrm{ad}$ libitum.

Four experiments were carried out to evaluate:

- in Experiment 1 and 2 - the effect of methods of oil separation from rapeseed on protein value and growth performance of rats ( $\mathrm{RSM} 1 \mathrm{vs} \mathrm{RC}_{\mathrm{enz}} 1$; RSM2 vs $\mathrm{RC}_{\mathrm{enz}} 2$ and $\mathrm{RC}$ ),

- in Experiment 3 - the effect of heat treatments of the cake produced on pilot scale on its protein value $\left(\mathrm{RC}_{0}, \mathrm{RC}_{\text {aut }}, \mathrm{RC}_{\mathrm{t} 120}, \mathrm{RC}_{1140}\right)$,

- in Experiment 4 - the influence of successive steps of industrial processing of the cake on its protein value and growth performance of rats $\left(\mathrm{RC}_{\mathrm{pp}}, \mathrm{RC}_{\mathrm{p}}, \mathrm{RC}_{\mathrm{t}}\right.$, $\mathrm{RC}_{\mathrm{th}}$ ).

\section{Chemical and statistical analysis}

Chemical composition of rapeseed products and nitrogen content in diets, digesta, faeces and urine were determined by conventional methods (AOAC, 1991). Amino acid composition of RSM 1 and the $\mathrm{RC}_{\mathrm{cn} z} 1$ used in experiment with pigs, and of digesta and faeces was determined according to methods described by Buraczewska et al. (1987) using Beckman Analyzer type 6300. Glucosinolates in rapeseed products were analysed by HPLC according to the ISO/DP 9167 method. 


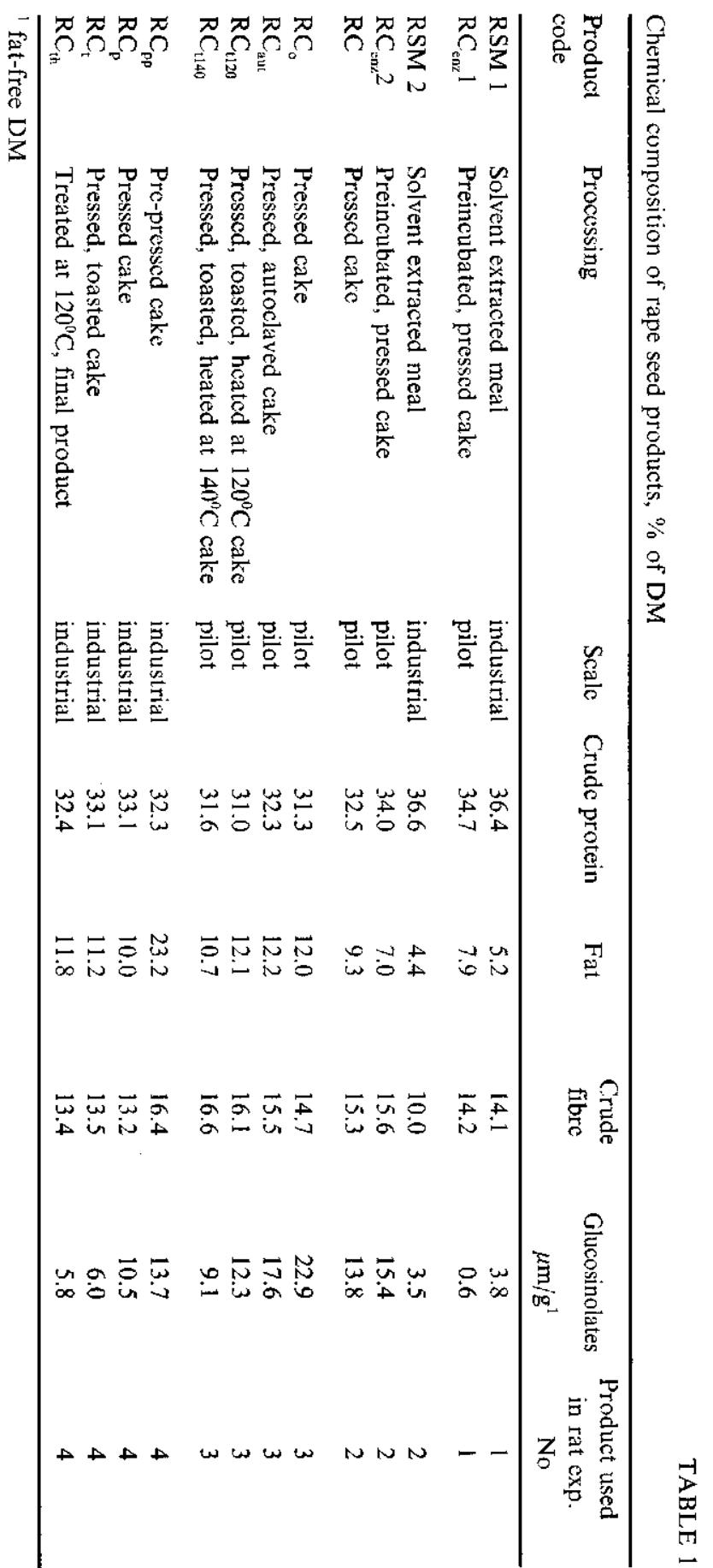


The statistical significance of differences was evaluated by one-factorial variance analysis using ,Statgraph. Plus var.7" Software.

\section{RESULTS}

\section{Chemical composition of rapeseed products}

Rapeseed cake produced both on pilot and industrial scale contained less protein (31-33 vs. 36\% of DM) and more fat (9-12 vs. 4-5\% of DM) than solvent extracted meal (Table 1). Activation of endogenous enzymes of the seed (incubation) prior to pressing resulted in a slight increase of protein and decrease of fat content in preincubated $\mathrm{RC}_{\mathrm{enz}} 1$ and $\mathrm{RC}_{\mathrm{enz}} 2$ in comparison with cake pressed without incubation (RC).

Heat treatment applied to press cake did not affect protein and fat content while crudc fibre content increased slightly as the intensity of heating on pilot scale increased. This tendency was not observed in the industrially processed cake.

Glucosinolate content was substantially lower in the standard solvent meal than in the cake, except for $\mathrm{RC}_{\mathrm{enz}} 1$ used in Experiment 1. Heat treatment applied to the cake on pilot scale reduced glucosinolate content progressively from 22.9 to $9.1 \mu \mathrm{m} / \mathrm{g}$ fat-free DM while during industrial processing the glucosinolates content decreased progressively from 13.7 to $5.8 \mu \mathrm{m} / \mathrm{g}$ fat-free DM. The level of these substances in the final product was low and only slightly higher than in the solvent extracted meal.

Amino acid composition of protein of $\mathrm{RSM}$ and $\mathrm{RC}_{\mathrm{en} 2} 1$ (Table 3) was similar, however a tendency was observed to lower content of most amino acids, especially lysine, in cake than in meal protein ( $4.91 \mathrm{vs.} 5.76 \mathrm{~g} / 16 \mathrm{gN}$ ).

Effect of methods of oil separation on the nutritional value of rapeseed products for pigs and rats

The results of protein and amino acid digestibility estimation in pigs fed on diets containing solvent meal (RSM1) and preincubated cake $\left(\mathrm{RC}_{\mathrm{enz}} 1\right)$ are presented in Table 2 . Ileal digestibility of protein, glutamic acid, lysine and methionine in the preincubated cake was lower than in the meal $(P \leqslant 0.05)$, the greatest difference was found for lysine ( 57.8 vs $72.3 \%$ ). Only aspartic acid digestibility was greater in the cake than in the meal. The method of oil separation affected also the total digestibility of amino acids. The digestibility of proline, glycine, lysine, his idine and tryptophane was lower and of leucine was higher $(\mathrm{P}<0.05)$ in the cake than in the meal. The smaller difference was found 


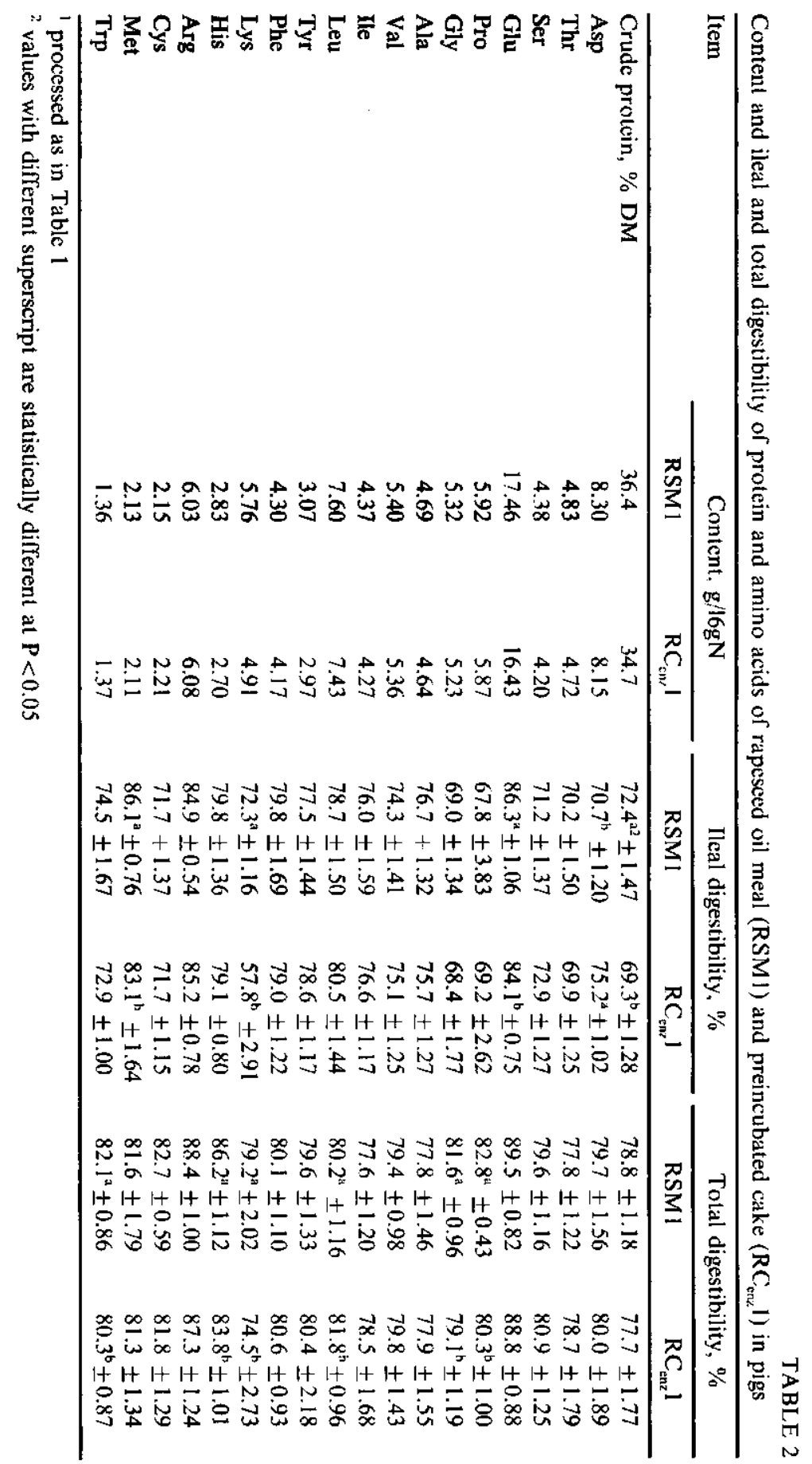


TABLE 3

Effects of methods of oil separation from rapeseed on protein value and growth performance of rats (Experiment 1 and 2)

\begin{tabular}{|c|c|c|c|c|c|}
\hline \multirow[b]{2}{*}{ Rapeseed products' } & \multicolumn{2}{|c|}{ Experiment 1} & \multicolumn{3}{|c|}{ Experiment 2} \\
\hline & RSM & $\mathrm{RC}_{\mathrm{el1z}} \mathrm{l}$ & RSM2 & $\mathrm{RC}_{\mathrm{enz}} 2$ & $\mathrm{RC}$ \\
\hline Protein digestibility (TD) & $77.6^{\mathrm{a} 2}$ & $77.4^{\mathrm{a}}$ & $79.2^{\mathrm{ab}}$ & $78.3^{\mathrm{a}}$ & $80.9^{\mathrm{b}}$ \\
\hline Biological value (BV) & $86.8^{\mathrm{a}}$ & $78.8^{\mathrm{b}}$ & $83.5^{\mathrm{ab}}$ & $81.9^{\mathrm{a}}$ & $86.1^{\mathrm{b}}$ \\
\hline Net Protein Utilization (NPU) & 67.4 & 61.0 & 66.1 & 64.1 & 69.6 \\
\hline Feed intake, $\mathrm{g} / 21$ days & 373 & 277 & 272 & 279 & 268 \\
\hline Body weight gain, g/21 days & $108.5^{\mathrm{a}}$ & $60.0^{\mathrm{b}}$ & $86.2^{\mathrm{a}}$ & $98.7^{\mathrm{a}}$ & $91.6^{\mathrm{a}}$ \\
\hline Feed conversion, g/g & $3.44^{\mathrm{a}}$ & $4.62^{\mathrm{b}}$ & $3.15^{\mathrm{a}}$ & $2.83^{a}$ & $2.92^{\mathrm{a}}$ \\
\hline Thyroid weight, $\mathrm{mg} / 100 \mathrm{~g} \mathrm{BW}^{3}$ & $8.8^{\mathrm{a}}$ & $19.2^{\circ}$ & $10.3^{\mathrm{a}}$ & $14.1^{\mathrm{b}}$ & $14.0^{\mathrm{b}}$ \\
\hline Liver weight, $\mathrm{g} / 100 \mathrm{~g} \mathrm{BW}$ & $5.7^{\mathrm{a}}$ & $7.1^{6}$ & $6.0^{a}$ & $6.4^{a}$ & $6.1^{a}$ \\
\hline
\end{tabular}

1 processed as in Table 1

${ }^{2}$ means in rows (within experiment) with different superscript are statistically different at $\mathrm{P}<0.05$

${ }^{3}$ body weight

between total lysine digestibility of the two products than respective difference between ileal digestibility.

The results of evaluation of cakes and standard solvent meal on rats are presented in Table 3. The preincubated cake used in Experiment $1\left(R_{\mathrm{enz}} \mathbf{l}\right)$ had significantly lower BV than the oil meal (RSM1), and affected growth performance indices negatively $(\mathrm{P}<0.05)$.

On the contrary, the second batch of preincubated cake used in Experiment $2\left(\mathrm{RC}_{\mathrm{enz}} 2\right)$ had similar $\mathrm{BV}$ as the oil meal (RSM2), but significantly lower than the cake processed without incubation (RC). In Experiment 2 different methods of oil separation had no effect on growth performance of rats. However, in both experiments thyroid weight in animals fed on diets with cakes was significantly greater than in rats fed on diets containing solvent meal.

Effect of heat treatment of cake on the protein value for rats

Protein digestibility of the cake was not affected by autoclaving during $15 \mathrm{~min}$ at $120^{\circ} \mathrm{C}$ but it decreased due to toasting during $45 \mathrm{~min}$ at $100^{\circ} \mathrm{C}$ followed by additional heat moisture treatment at about $120^{\circ} \mathrm{C}$ (Table 4). The increase of heating temperature from 120 to $140^{\circ} \mathrm{C}$ did not induce further significant deterioration of TD. Neither of the heat treatments influenced BV or NPU of the cake. 
Effect of heat treatment on the protein value of rapeseed cake for rats (Experiment 3)

\begin{tabular}{|c|c|c|c|c|}
\hline Producl & Heat treatment & $\begin{array}{c}\text { True } \\
\text { digestibility } \\
\text { (TD) }\end{array}$ & $\begin{array}{l}\text { Biological } \\
\text { value } \\
\text { (BV) }\end{array}$ & $\begin{array}{l}\text { Net protein } \\
\text { utilization } \\
\text { (NPU) }\end{array}$ \\
\hline $\mathrm{RC}_{0}$ & none & $80.4^{1}$ & $91.0^{\mathrm{u}}$ & 73.2 \\
\hline $\mathrm{RC}_{\text {aut }}$ & $\begin{array}{l}\text { autoclaved at } 18 \% \text { moist. up to } 120^{\circ} \mathrm{C} \\
\text { during } 15 \text {, }\end{array}$ & $79.9^{\mathrm{bc}}$ & $91.5^{\mathrm{a}}$ & 73.1 \\
\hline $\mathrm{RC}_{1120}$ & $\begin{array}{l}\text { toasted at } 18 \% \text { moist. in } 100^{\circ} \mathrm{C} \\
\text { followed by short time pressure } \\
\text { treatment at } 120^{\circ} \mathrm{C}\end{array}$ & $77.1^{\text {ab }}$ & $91.9^{\mathrm{a}}$ & 70.8 \\
\hline $\mathrm{RC}_{1144}$ & $\begin{array}{l}\text { toasted at } 18 \% \text { moist. in } 100^{\circ} \mathrm{C} \\
\text { followed by short time pressure } \\
\text { treatment at } 140^{\circ} \mathrm{C}\end{array}$ & $76.6^{a}$ & $93.7^{\mathrm{a}}$ & 71.8 \\
\hline
\end{tabular}

${ }^{1}$ values with different superscripts are statistically different at $\mathrm{P}<0.05$

Effect of industrial processing on the nutritional value of the cake for rats

Full pressing of pre-pressed cake did not affect its protein value (Table 5). Toasting or toasting followed by short time heat moisture treatment (at about $120^{\circ} \mathrm{C}$ ) did not affect protein digestibility significantly but when the effect of both steps involving heating (unheated pre-pressed and full pressed cake vs. toasted and expeller cake) were pooled, the decrease of TD was significant. BV of protein did not deteriorate during processing.

TABLE 5 Effect of consecutive steps of industrial processing of rapeseed cake on protein value and growth performance of rats (Experiment 4)

\begin{tabular}{lcccc}
\hline Product & $\mathrm{RC}_{\mathrm{pg}}$ & $\mathrm{RC}_{\mathrm{p}}$ & $\mathrm{RC}_{\mathrm{t}}$ & Expeller cake $\mathrm{RC}_{\mathrm{th}}$ \\
\hline Protein digestibility (TD) & $81.2^{\mathrm{a} 2}$ & $80.3^{\mathrm{a}}$ & $78.5^{\mathrm{a}}$ & $78.1^{\mathrm{u}}$ \\
Biological value (BV) & $92.1^{\mathrm{a}}$ & $91.4^{\mathrm{a}}$ & $88.5^{\mathrm{a}}$ & $91.0^{\mathrm{a}}$ \\
Net Protein Utilization (NPU) & 74.8 & 73.4 & 69.5 & 71.1 \\
Feed intake, g/21 days & 262 & 276 & 283 & 278 \\
Body weight gain, g/21 days & $83.4^{\mathrm{a}}$ & $83.9^{\mathrm{a}}$ & $85.2^{\mathrm{a}}$ & $87.3^{\mathrm{a}}$ \\
Feed conversion, g/g & $3.18^{\mathrm{a}}$ & $3.31^{\mathrm{a}}$ & $3.33^{\mathrm{a}}$ & $3.19^{\mathrm{a}}$ \\
Thyroid weight, mg/ $100 \mathrm{~g} \mathrm{BW}$ & $20^{\mathrm{a}}$ & $16^{\mathrm{a}}$ & $13^{\mathrm{a}}$ & $11^{\mathrm{a}}$ \\
\hline
\end{tabular}

\footnotetext{
[ processed as in Figure $]$

${ }^{2}$ values with different superscripts are statistically different at $\mathrm{P}<0.05$

${ }^{3}$ body wcight
} 
Growth performance of rats fed on diets containing cake from four steps of processing was similar. The processing significantly affected the relative weight of thyroid gland which was reduced at each step from $20 \mathrm{mg} / 100 \mathrm{~g}$ body weight in animals fed on pre-pressed cake to $11 \mathrm{mg} / 100 \mathrm{BW}$ in those fed on toasted and heat moisture treated (expeller cake).

\section{DISCUSSION}

Comparison of the technology of oil separation showed that simple pressing as compared with solvent extraction affects rather chemical composition of the product than its protein value. Lower protein and higher fat content in cake than in meal are the consequence of less efficient removal of oil and are in agreement with respective values found by Rakowska and Ochodzki (1995) for rapeseed cakes and meals of European production. The lower glucosinolate content in meal than in non-heated cake is mainly due to the effect of toasting, as it was found by many authors (Shires et al., 1983; Dąbrowski et al.,1989; Katzer and Mińkowski, 1989).

The results of balance experiments with rats indicating for similar digestibility and biological value of the cake and meal protein, are consistent with the results of Grala et al. (1994) and Rakowska and Ochodzki (1995).

However, contrarily to the results of these authors, we did not observe any difference in growth performance of rats fed on cake and meal diets, in spite of greater thyroid weight in rats fed on cake.

It is well known that glucosinolates have adverse effect on thyroid functions and growth performance (Mawson et al., $1994 \mathrm{a}, \mathrm{b}$ ). It may be therefore assumed that similar feed intake and growth rate in animals fed on cake and on meal in our experiment are related to a rather small goitrogenic effect of evaluated cake (thyroid weight 14 vs. $10 \mathrm{mg} / 100 \mathrm{~g}$ body weight in rats fed on cake and meal, respectively), smaller than that found by Grala et al. (1994) (16.5 vs $7.5 \mathrm{mg} / 100 \mathrm{~g}$ body weight).

Since the level of glucosinolates in double low rape seeds may vary to some extent and since their effect may be more detrimental in longer periods of feeding rapeseed, it was concluded that moderate heat treatment of the cake should be applied to reduce the effects of feeding cake on thyroid functions and, in consequence, on animal performance.

Preincubation of rapeseed prior to pressing influenced negatively nutritional quality of the cake. The lower biological value of protein of the cake used in Experiment 1 may be explained by the smaller content of lysine and drastic reduction of ileal digestibility of this amino acid found in pigs. The actual reasons of this deterioration are not known; it cannot be ascribed to heat treatment since 
the conditions of incubation were mild. The negative effect of activation native seed enzymes contrasts with findings of Jensen et al. (1991) who obtained rapeseed meal of a high biological value of protein using a multi-enzyme preparation degrading cell walls.

Hypertrophy of thyroid and liver in rats fed on pre-incubated cake, in spite of an exceptionally low level of glucosinolates, may also indicate for enzymatic transformation of these substances into compounds affecting metabolism. The results of pilot trials with preincubation were not encouraging for this method.

The experiment conducted to evaluate the effects of heat treatments applied post-pressing on pilot scale showed that autoclaving at $120^{\circ} \mathrm{C}$ during $15 \mathrm{~min}$ affected neither digestibility nor biological value of protein while toasting at $100^{\circ} \mathrm{C}$ during $45 \mathrm{~min}$ followed by a short time heat moisture treatment to 120 or $140^{\circ} \mathrm{C}$ reduced progressively but to small extent protein digestibility and had no effect on biological value of protein. These results are in agreement with those of Jensen et al. (1994) who found that prolongation of toasting of rapeseed meal in $100^{\circ} \mathrm{C}$ from 0 to 15,30 and 60 min caused a slight decrease of TD without any effect on BV of protein, which was depressed only when the meal was toasted during $120 \mathrm{~min}$. In the study of Grala et al. (1994) reduction of BV of defatted cake was observed after $30 \mathrm{~min}$ of toasting at $100^{\circ} \mathrm{C}$ and $10 \mathrm{~min}$ at $120^{\circ} \mathrm{C}$ while TD of protein decreased when time of heating at $120^{\circ} \mathrm{C}$ was extended.

It may be concluded that the impairment of protein value expressed as TD and BV does not take place when rapeseed meal or cake is heated either at higher temperature during short time (up to $120^{\circ} \mathrm{C}$ and $15 \mathrm{~min}$ ), or longer time at lower temperature (at $100^{\circ} \mathrm{C}$ up to about $60 \mathrm{~min}$ ).

The evaluation of the effects of the chosen pressing and heating parameters applied on the industrial scale confirmed the results obtained with cake produced in the pilot plant. Neither of the consecutive steps of the process had significant effect on protein value of the cake except for slightly lower protein digestibility of the two heat treated cake (two last steps) than the nontreated. This small negative effect of heating on protein digestibility is in agreement with previous observations. Glucosinolate content in the cake decreased progresively during processing, which was accompanied by the decrease of thyroid weight in rats fed on respective products. Growth parameters of the animals were not affected by the processing.

Protein value and other parameters reflecting nutritional value of the final industrial product - expeller cake - were similar to those found for the solvent extracted meal in the first part of the study. The results allow for the conclusion that the protein value of the cake obtained with the developed pressing technology is comparable to that of the solvent extracted meal. 


\section{REFERENCES}

Anderson-Hafermann J.C., Zhang Y., Parsons C.M., 1993. Effects of processing on the nutritional quality of canola meal. Poultry Sci. 72, 326-333

Association of Official Analytical Chemists, 1975. Official Methods of Analysis, 12th ed. AOAC, Washington, DC

Buraczewska L., Schulz E., Schröder H., 1987. lleal digestibility of amino acids in pigs fed barleys differing in protein content. Arch. Anim. Nutr. 37, 861-867

Dąbrowski K.J., Rutkowski A., Mammimanna S.G., Rowicka A., 1989. The reduction of glucosinolate and sinapine contents, under industrial processing of rapeseed. Fat Sci. Technol. 9, 361-363

Grala W., Pastuszewska B., Smulikowska S., Buraczewska L., Gdala J., 1994. Effect of thermal processing on the protein value of double-low rapeseed products. 2. Effect of processing stages in the oil plant and of toasting in laboratory conditions. J.Anim. Feed Sci. 3, 43-55

Isobe S., Zuber F., Kemura K., Noguchi A., 1994. Oil expression of rapeseed with twinscrew expeller. Proceedings of 8th International Rapeseed Congress, Saskatoon (Canada), pp. 767-769

Jensen S.K., Liu Y.G., Eggum B.O.,1995. The effect of heat treatment on glucosinolates and nutritional value of rapeseed meal in rats. Anim. Feed Sci. Technol. 53, 17-28

Jensen, S.K., Olsen, H.S., Sörensen H., 1991. Processing of oilseed rape at gentle conditions resulting in limited glucosinolate degradation and fractionation into hulls, oil, syrup and protein rich meal. Proceedings of 8th International Rapeseed Congress, Saskatoon (Canada), pp. 1890-1897

Katzer A., Mińkowski K., 1989. Observations of the commercial double-low rapeseed processing (in Polish). Tłuszcze jadaine 37, (4), 20-30

Loutas P.A. 1991. Closing summary. Procecdings of 8th International Rapeseed Congress, Saskatoon (Canada), pp. 1935-1936

Mawson R., Heaney R.K., Zduńczyk Z., Kozłowska H., 1994a. Rapeseed meal-glucosinolates and their antinutritional effect. Part 3. Animal growth and performance. Nahrung 38, 167-177

Mawson R., Heaney R.K., Zdunczyk Z., Kozłowska H., 1994b. Rapeseed meal-glucosinolates and their antinutritional effect. Part 4 . Goitrogenicity and internal organ abnormalities. Nahrung $38,178-191$

Rakowska M., Ochodzki P., Sørensen H., 1995. Chemical and biological evaluation of rapesced meals derived from 5 countries, obtained with different processing procedures. Proceedings of the 8th International Rapessed Congres, Cambridge, pp. 203-205

Shires A., Bell J.M., Blair R., Blake J.A., Fedec D., McGregor D.J., 1983. The feeding value of canola meal for broiler chickens as affected by heat and steam during desolventation and by fibre reduction. Research on Canola Seed, Oil, Meal and Meal Fractions. Canola Council or Canada, Winnipeg, Manitoba 61, 12-16

\section{STRESZCZENIE}

\section{Wplyw technologii wytlaczania oleju i ogrzewania na wartość odżywczą biakka wytloku z rzepaku niskoglukozynolanowego}

Celem badań było określenie wpływu dwóch metod wytłaczania (po i bez inkubacji nasion) oraz ekstrakcji oleju z rzepaku podwójnie ulepszonego, a także różnych warunków ogrzewania wytłoku, na skład produktów i wartość odżywczą bialka. Wytłok rzepakowy zawierał więcej thuszczu (9-12 vs 
4-5\% SM) i mniej białka (31-33 vs 36\% SM) niż śruta poekstrakcyjna, natomiast oznaczona na szczurach strawność i wartość biologiczna białka wytłoku i śruty byly podobnc (odpowicdnio $80,9 \mathrm{vs}$ 79,2 i 86,1 vs 83,5 ). Wpływ inkubacji nasion r7epaku przed wytłacraniem, mającej na celu uruchomienie enzymów nasienia, różnił się między dwiema partiami wytłoku. Pierwsza partia wytloku z nasion inkubowanych zawierała mniej lizyny $(4,91$ vs $5,7 \mathrm{~g} / 16 \mathrm{~g} \mathrm{~N})$, strawność lizyny w jelicie cienkim świń była mniejsza $(57,8$ vs $72,3 \%$ ), wartość biologiczna białka dla szczurów była niższa $(78,8$ vs 86,8$)$ niż śruty pockstrakcyjncj; wartość biologiczna białka drugicj partii wytloku, ocenianej tylko na szczurach, była wyższa niż pierwszej partii i nie różniła się istotnie od wartości białka śruty, lecz była niższa od wartości wytloku z nasion nieinkubowanych. Ogr/ewanie wytłoku na skalę pilotową (autoklawowanie lub tostowanie, a następnie ogrzewanie w temp. $120^{\circ} \mathrm{C}$ lub $140^{\circ} \mathrm{C}$ ) zmniejszyło zawartość glukozynolanów z 22,9 do $9,1 \mu \mathrm{m} / \mathrm{g}$ beztluszczowej SM i w nicwiclkim stopniu zmnicjszato strawność (z 80,4 do 76,6), lecz nie wartość biologiczną białka.

Każdy z kolcjnych etapów przemysłowej technologii wytłacrania (wytłacranie wstępne, wythaczanie całkowite, tostowanie, ogrzewanie) powodował zmniejszenie zawartości glukozynolanów (z 13,7 do $5,8 \mu \mathrm{m} / \mathrm{g}$ beztluszczowej SM), nie wpływał natomiast na wartość odżywczą bialka i wyniki testów wzrostowych.

$\mathrm{Na}$ podstawic przeprowadzonych badań wyciągnięto wniosek, że wartość odżywcza białka prawidłowo ogrzewanego wytłoku rzepakowego jest podobna do wartości białka poekstrakcyjnej śruty rzepakowej. 